\title{
Stronger communities? Changing prospects for community-led strategic planning in New Zealand
}

\author{
Bruno Brosnan \\ Marlborough District Council \\ New Zealand

\section{Christine Cheyne} \\ Massey University \\ New Zealand
}
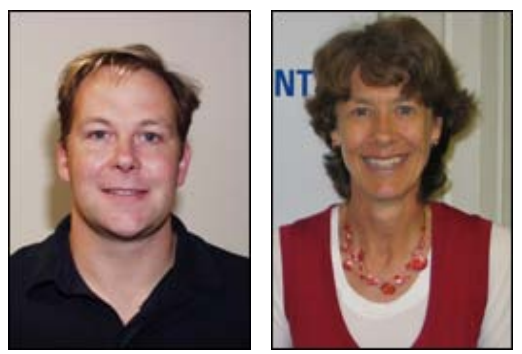

\begin{abstract}
New Zealand's Local Government Act 2002 ushered in a new phase in local government, a phase that is best characterised by the term 'empowerment'. Not only were councils empowered to promote social, economic, environmental and cultural well-being, in contrast with previous more prescriptive legislation, but citizens were empowered to engage in community-led strategic planning. In many respects the new statute reflected contemporary international public management trends in which governance is increasingly being conducted via networks of public and private actors. However, with the change of government from a centre-left Labour-led coalition to a centre-right National-led government following the November 2008 general election, it is less certain that local government and communities will continue to experience a strengthening of the pluralisation of governance that has been a feature of the past decade. This article argues that the potential disempowerment of local government, and possible attenuation of community-led strategic planning in New Zealand, comes at a time when the momentum for devolution to local government and other communities is increasing elsewhere.
\end{abstract}

\section{Keywords}

New Zealand Local Government, Network Governance, Community-Led Strategic Planning. 


\section{Introduction}

Since 2008, local government in New Zealand has been the focus of two major reviews which have potentially far-reaching consequences for local democracy. First, following a change of government from a centre-left Labour-led coalition to a centre-right Nationalled government, in November 2008 legislation was passed which establishes a new Auckland Council from 1 November 2010, replacing the eight councils that previously existed. From 1989, the Auckland area, which has over a third of New Zealand's population, was governed by the Auckland Regional Council and seven territorial authorities. The new Auckland Council is New Zealand's largest unitary authority and represents a new approach to regional government in contrast with the past in which unitary councils were confined to largely rural regions. ${ }^{1}$ There are strong expectations of further amalgamations in other regions following triennial local elections in October 2010, once the new Auckland governance arrangements are in place.

As well as the reform of Auckland governance, in April 2009 a second reform initiative was instigated. Known as the 'TAFM review', this process is concerned with improvements to Transparency, Accountability and Financial Management. While this review has direct consequences for the wider local government sector, it has been overshadowed by the Auckland government reform legislation. There has been minimal media coverage of the TAFM review and it appears to be unknown, not just to most of the general population in communities throughout New Zealand, but also to many elected members and those working in the sector. The purpose of this article is to outline the changes to community-led local strategic planning that are proposed as part of this review. In the first section of the article, we look at the recent history of local authority strategic planning and public participation in local government and situate this in the broader context of changing views about the role of government. This context has been dominated by a focus on a networked approach to governing, termed governance. The notion of governance has had particular salience at the local level. In the second section we outline the TAFM review. The final section considers the implications of both this

\footnotetext{
${ }^{1}$ New Zealand has a two-tiered system comprising multi-purpose regional councils and territorial authorities (city and district councils). Unitary authorities perform the functions of both regional councils (e.g. regional planning and environmental management) and territorial authorities (e.g. subregional land-use planning and community services). There have been only four unitary authorities since the early 1990s, all of them with a small population in mainly rural and relatively isolated parts of the country.
} 
review and the continuing momentum internationally for participatory governance networks.

\section{Governing Beyond the Centre}

From the mid- $19^{\text {th }}$ century, New Zealand's colonisers ensured legislation reflected the prevailing English view of providing infrastructure, services and regulation (Wood \& Rudd 1996, Cheyne 2002, Miller 2006). Central government dominated the country's governance arrangements (Bush 1980, Kelsey 1993, Mulgan 1994, Wood \& Rudd 1996, Gwynn 1998, Myers 1998, Wood 2002, Leonard \& Memon 2006) with local government performing a narrow range of functions. Local government was to be controlled through statutorily prescribing its functions, rather than empowered (Bush 1980 Cheyne 2002, 2006). Central government was the designer of policies and provider of resources that the communities needed, with local government having a narrow mandate for certain functions - largely relying on locally-raised revenue but, in some cases, with central government funding (Bush 1980, Kelsey 1993, Mulgan 1994, Wood \& Rudd 1996, Gwynn 1998, Myers 1998, Wood 2002, Leonard \& Memon 2006).

Traditionally, therefore, New Zealand local government has focused on provision of network infrastructure (roads, wastewater, drinking water, stormwater), disposal of waste, and environmental regulation. Up until 2002, local government's role was determined in a 'top-down' manner with central government prescribing the functions and powers of local government and prohibiting activity that was not specifically mandated (Bush 1980, Kelsey 1993, Mulgan 1994, Wood \& Rudd 1996, Gwynn 1998, Myers 1998, Perkins \& Thorn 2001, Cheyne 2002, Richards 2002, Wood 2002, Freeman 2004, Cheyne 2006, Miller 2006, Leonard \& Memon 2008).

During the 1980s and 1990s there was growing discontent with a cumbersome, overlyprescriptive local government statute, and a desire to strengthen local government and local democracy. Commentators noted frustration with slow, costly, and often duplicated work of government (Wood 1988, Bush 1990, Mulgan 1994, Wood \& Rudd 1996).

This increasing dissatisfaction was largely aimed at historical governance modes of hierarchical control and regulation (Martin 2003, Cowell 2004, Scott et al. 2004, Head 2007, Lee 2009). At the same time, internationally, there was a movement of rediscovery and revitalisation of civil society, improved communication technologies and access to 
information (Reddel 2002, Berger, 2003, Head 2007, Hughes 2007). Many planning practitioners and some managers in New Zealand local government were aware of the emerging body of literature around community-based planning ${ }^{2}$ (Lane \& Corbett 2005, Head 2007, Uitermark \& Duyvendak 2008), and in the United Kingdom, distinct moves were occurring in the late 1990s to introduce a new statutory framework for communityled strategic planning. ${ }^{3}$

Political rhetoric around this time focused on the high level of dissatisfaction with the prescriptive nature of previous legislation (Gwynn 1998, DIA 2000, DIA 2001, Cheyne 2002, Cousins 2002, Richards 2002, Rive 2003), the burgeoning sizes of municipalities (Business New Zealand 2001) and outrage at ever-increasing compliance costs and rates (Myers 1998, Business New Zealand 2001). Unsurprisingly, the end result of the election was a change in government. Almost immediately, the new government sought to revamp a number of the legislative tools to increase government efficiency and decrease costs in the process (DIA 2000). The government sought to create legislation that strengthened local authorities' connections to their local communities, codify responsibilities for sustainability and increase accountability to communities (DIA 2000, DIA 2001, Cheyne 2002, Cheyne 2006, Local Futures 2006, Leonard \& Memon 2008). In embarking on this reform process the new government sought to create new legislation with a number of key differences from its predecessors (Wood \& Rudd 1996) but which also represented a paradigmatic shift from command-and-control to networked and participatory governance (Leonard \& Memon 2008).

It is not the purpose of this article to discuss in detail the broader international context in which this paradigmatic shift was situated. However, we note that from the late 1990s there was a burgeoning of literature on the notion of government beyond the centre, or even governing without government (Rhodes, 1996, Rhodes 1997, Stoker 1998, Berger 2003, Haus et al., 2004, Geddes, 2005, Geddes, 2006, Klijn, 2008, Chhotray and Stoker 2010, Blakely 2010, Guaranos-Mesa and Geddes, 2010). This large body of literature reflects the use of the term 'governance' has been used in very diverse disciplinary,

\footnotetext{
2 The term 'community-based planning' refers to a range of participatory planning approaches including both those led by central and local government and those where citizens and community groups are a catalyst for community involvement. These include participation in the traditional concerns of land-use planning but also more broadly in budgeting and other strategic planning processes at the local level.

3 'Community-led strategic planning' refers specifically to more recent initiatives which promote strategic planning at the community level and by the community. While this may be facilitated by local government there is a deliberate intention to ensure that there is community 'ownership' of the process as opposed to strategic planning by and for a council organisation.
} 
organisational and geographical loci. Rhodes (1996: 653) notes at least six different uses of the term: the notion of the minimal state; corporate governance, the new public management; 'good governance'; socio-cybernetic systems; and self-organizing networks. For our purposes, we recognise that the growing emphasis on collaborative working and partnerships between local government and key stakeholders has been, in part, a response to challenges at the local level similar to those faced by central government, namely, achieving solutions to 'wicked problems' such as social exclusion, environmental degradation, inequality, climate change which governments alone seem incapable of resolving.

Community engagement in strategic planning provided a stimulus to other forms of engagement, indeed, the concept of governance does not confine networks of actors to strategic planning but encompasses networks for the purposes of monitoring and reporting on plan implementation as well as service provision and management of resources. Hence there is often an overlap of terminology, especially when referring to governance at the local level, and a blurring of distinctions between concepts such as local governance, devolution, collaboration and partnerships.

Recognising the changing nature of government, and the need for responsiveness to communities, from the outset of the reform process, the Labour-led government wished to articulate, in statute, a requirement or responsibility to develop new relationships between central government (Memon \& Thomas 2006, Hewison 2008), local authorities and communities (Scott et al. 2004, Larner \& Craig 2005, Hewison 2008, LGC 2008). Policy-makers believed that strengthening local communities through local partnerships would help New Zealanders to respond more positively to economic and social change (Richardson 2005, Local Futures 2006, Memon \& Thomas 2006, Lee 2009), allow for the sharing of 'best practice' knowledge and practices (Richardson \& Winefield 2007), and more nuanced understandings of the local needs those practices must meet (Larner \& Craig 2005, Richardson \& Winefield 2007). The policy intent was that central and local government be viewed as two arms of the same system, with a shared focus on contributing positively to the well-being of communities. More importantly, an intent that local government along with community groups, non-governmental organisations and businesses need to work together to find solutions and advance the aspirations of local communities (LGC 2008, Lee 2009). 
This political rethink created several new pieces of legislation that revolutionised political processes and created opportunity for community involvement in the planning process (Dann 1992, Cheyne 2002, Cheyne 2006, Leonard \& Memon 2008). The Resource Management Act 1991 provided an environmental regulatory tool based on sustainable management and participation (Perkins \& Thorn 2001, Freeman 2004, Leonard \& Memon 2008). The heart of this document was the sustainable management of all natural and physical resources (Perkins \& Thorn 2001, Freeman 2004). Decisionmakers were not only required to talk to the present community, they were required to consider the future needs of the community (Dann 1992, Freeman 2004, Leonard \& Memon 2008) and take account of the past (Part 2 - Historic Heritage considerations). The electoral system was also changed in the interest of increased representation and participation (McRobie 1985, Atkinson 2003), as well as the Rating Powers Act, and the Local Election and Polls Act (DIA 2001). However, it was the review of the main local government statute that provided the most significant changes to local political processes.

\section{Giving the Community a Voice}

The forces at work in New Zealand through the 1980s and 1990s finally prompted a major review of local government in 2000-2001 following the election of a Labour-led government in 1999. That review culminated in the Local Government Act 2002 (LGA 2002), which provided a broad empowerment of local government similar to a power of general competence, and promoted a collaborative planning process by local authorities that engaged central government and a wide range of local stakeholders (Perkins \& Thorns 1999, Department of Internal Affairs [DIA] 2000, DIA 2001, Cheyne 2002, Memon 2002, Cheyne 2006, Local Futures 2006, Memon and Thomas 2006, Leonard \& Memon 2008, Local Government Commission [LGC] 2008, Nyseth and Ringholm 2008, Lee 2009). The LGA 2002 also contained reporting requirements against which local authority performance and progress towards a long-term vision would be measured (Local Futures 2006, Richardson \& Winefield 2007, Leonard \& Memon 2008, Society of Local Government Managers 2009a, 2009b, Ministry for the Environment 2009a, 2009b). Community-led strategic planning in New Zealand thus entered a new paradigm (Lane and Corbett 2005, Larner and Craig 2005, Thomas and Memon 2005, Houston and Katavic 2006, Memon and Thomas 2006, Waiheke Island Sustainable Development Group 2007, Hewison 2008, Leonard and Memon 2008, Lee 2009). 
The LGA 2002 set out the role and purpose of local government and provided for councils to work collaboratively with other councils and with other public and private organisations in order to be able to advance community goals (DIA 2000, DIA 2001, Cousins 2002, Local Government New Zealand 2003, Wilson \& Slater 2003, Larner \& Craig 2005, Thomas \& Memon 2005, Cheyne 2006, Local Futures 2006, Memon \& Thomas 2006, Hewison 2008, Local Government New Zealand 2009, New Zealand Government 2009). During the reform the government stated that the new Act needed to provide a coherent overall strategy on local government (DIA 2000, DIA 2001, Richards 2002, DIA 2009). By providing a purpose, local government had validation for its existence (Richards 2002, Memon \& Thomas 2006) and a framework it could work within and be measured against (DIA 2000, DIA 2001, DIA 2009). The new Act confirmed local authorities as the mechanism by which local communities promote social, economic, environmental and cultural well-being (Cousins 2002). The framework clarified the process and opportunities for individuals and organisations to influence the decisions that their local authorities make (Cousins 2002).

The LGA 2002 provided a broad empowering legislative framework under which local authorities could meet the needs of their communities (DIA 2000, DIA 2001, Local Government New Zealand 2003, DIA 2009). This framework could then be seen as creating a mandate for community governance (Leonard \& Memon 2008). The Act required local authorities to be more responsive to the community, and to provide opportunities for citizens to have input into planning processes, in particular, through the statutory visioning exercise known as the 'community outcomes' process and through the development of the Long-Term (ten-year) Council Community Plan (LTCCP) (DIA 2001, Richards 2002). The LTCCP is required to describe all local authority activities, how the local authority pays for them, and how the activities contribute to community well-being.

The LGA 2002's predecessor, the Local Government Act 1974, prescribed councils power and functions in detail resulting in an overwritten, difficult to understand, reactive Act (Richards 2002). The 2002 Act empowers councils to promote social, economic, environmental and cultural well-being which is, in effect if not in name, a power of general competence (Richards 2002, Memon \& Thomas 2006). Albeit with not unfettered powers, local government has the full capacity to undertake activities and full rights and privileges for the purposes of undertaking local government. This means that 
local authorities have the same rights and freedoms of action, consistent with general laws, as individuals and corporations. Unlike the previous states, councils have a broad discretion over the activities they can become involved in, without the need for prescription in law.

In direct response to increased powers for local authorities, the government imposed rigorous provisions for governance and accountability to local communities (DIA 2000, DIA 2001, Memon \& Thomas 2006). Governance is a key role of local authorities (Richards 2002) and the Act provides principles and other provisions to ensure that elected members are responsible, open, transparent, and democratically accountable in their decision-making. The Act requires authorities to facilitate and identify community views, translate community wishes into defined outcomes, monitor, evaluate, and report to the community on performance (DIA 2001, Richards 2002). Local authorities are required to plan for and report on the effect of their activities on the four well-beings to their local communities (Controller and Auditor-General 2006a). Accountability is not achieved until the audited information is made available to ratepayers in a user-friendly format (Controller and Auditor-General 2006b).

The LGA 2002 provides that the principles of the Treaty of Waitangi are relevant to local authorities (DIA 2001). The Act contains specific principles and mechanisms to improve the effectiveness of the operation of local government decision-making processes, enhance opportunities for the participation of Māori in local government, and provide for appropriate accountability mechanisms as to the effectiveness of the operation of local government to Māori (DIA 2001). Central government recognised that local government plays an important role in the relationships between Māori and the Crown, and that much of what Local Government does is directly relevant to the active protection of Māori culture and way of life (DIA 2000, DIA 2001). However, it also recognised that Māori are under-represented on councils and that the level of participation in local elections is low (DIA 2000, DIA 2001). Therefore, the Act requires that councils work for Māori communities as well as for others (DIA 2000, DIA 2001).

\section{Kicking the Local Government Tyres?}

The LGA 2002 contains within it reporting requirements that can be assessed. The Controller and Auditor-General reports triennially to central government on the results of its audits of local government, in order to encourage 'best practice'. In addition, central 
government periodically initiates reviews on issues of significance to identify areas appropriate for legislative or other clarification or amendment.

The 2005/2006 review of local government (Controller and Auditor-General 2006b) and the review of the 2006-2016 LTCCPs (Controller and Auditor-General 2006a) by the Controller and Controller and Auditor-General highlighted several concerns about the capacity and the desire of local councils to meet the requirements of the LGA 2002. In both reviews, the Auditor-General expressed concerns about timeliness and report quality being provided to local communities by councils (Controller and Auditor-General 2006a, Controller and Auditor-General 2006b). More disappointingly, the Controller and Auditor-General expressed concern about the lack of LTCCPs being used as a strategic and user-centric planning document (Controller and Auditor-General 2006a). If authorities are not using the LTCCPs as intended, the purpose of local government may not be fully realised.

The 2007 report of the Local Government Rates Inquiry (LGRI) highlighted the need for improved consultation by councils (LGRI 2007), echoing concerns similar to the Controller and Auditor-General that councils are not communicating to the community they serve and are creating unsustainable rating increases (LGRI 2007). The report recommends that central government provide funding, expand rate rebate programmes, reduce rating complexity through legislation, and co-ordinate with local government (LGRI 2007). Overall, the report recommends local government show restraint on expenditures and priorities (LGRI 2007).

The 2008 review of the LGA 2002 (LGC 2008) again identified no great problem with the Act but more with its implementation by individual authorities. The report purpose was to review the Local Government Act to see if any of the Act's provisions or if any of the ways that councils are operating as a barrier to achieving policy intent (LGC 2008). The findings indicate that the Act is sound and that it is more the interpretations and understandings of the Act's critical provisions by authorities which are making the operation of this Act more demanding that it needs to be (LGC 2008). Overall, the report recommended more dissemination of information on good practice and support for local authorities rather than major legislative reform (LGC 2008). 
By contrast, following an extensive inquiry and consideration of thousands of public submissions, the Royal Commission on Auckland Governance which reported in March 2009 recommended significant change to local government in the Auckland region, and highlighted the need for more joined-up and collaborative governance arrangements, encompassing not just local and central government but other key economic and social actors including the social services sector and iwi (Māori tribes) (RCAG 2009). Although the government ignored many of the recommendations of the Royal Commission it has proceeded with structural reorganisation: the so-called 'super-city'. Critics consider that the new unitary council that will be established from 1 November 2010 will escalate costs and bureaucracy (Hansard 2009, Weber \& Saunders 2009), increase the distance between citizens and elected members, and diminish progress being made by the previous councils towards social, cultural, environmental well-being (Humpage 2009, Hansard 2009, Weber \& Saunders 2009).

Overall, however, the main recommendations from recent enquiries and reports on local government focus on building the capacity of councils to interpret and apply the provisions of the LGA 2002. These reviews, as well as numerous independent assessments by academic researchers, have generally found the Act to be sound and have validated the new planning paradigm and framework for community-led strategic planning, notwithstanding some issues associated with capacity and interpretation by some councils (Controller and Auditor-General 2006a, Controller and Auditor-General 2006b, Richardson \& Winefield 2007, Controller and Auditor-General 2009, Controller and Auditor-General 2010). Despite that validation, following the change of government in 2008, the new Minister of Local Government, Rodney Hide, introduced legislation in March 2010 to amend the Local Government Act. In the view of the government, and in particular the Minister, the framework is flawed and in need of reform (Beatson 2009, Eames 2009, Hansard 2009).

The Minister's explicit goal, as the leader of a libertarian party that is junior Coalition partner in the National-led government, is to limit the activities of local government to a narrow range of core services and to streamline the long-term community planning processes. This reform agenda, if achieved, would undermine both the broad empowerment of local government that occurred from 2002, and an increasingly wellestablished long-term planning process characterised by strong community engagement. 
Perhaps foreshadowing the National-led government's future intentions for reduced community involvement in long-term community planning, the creation of the new Auckland Council has resulted in a significant worsening of the representation ratio in New Zealand's largest metropolitan-region. Elected members on the Auckland Council will represent an average of 65,000 constituents. A further review, discussed later in this paper, the Transparency, Accountability and Financial Management (TAFM) review, seeks to alter the current statutory framework for community-led strategic planning in a way that is likely to diminish public participation in local strategic planning.

\section{Moving Forward - and Backwards}

The theoretical assumptions underpinning the LGA 2002 are that partnerships are mutually beneficial and that efforts to 'join together' different organisations will create more than the sum of the parts. In order to achieve this outcome, authorities are provided considerable discretion in their conduct. However, this discretion may be seen as an opportunity to provide flexibility or for questionable practice.

The LGA 2002's main strengths lay in its blend of flexible and prescriptive approaches to decision-making, the planning process and accountability (Scott et al. 2004, Lee 2009). The provisions are largely consistent with the literature in terms of successful community engagement and partnerships (Thomas \& Memon 2005). The legislation provides local authorities the freedom to use any consultation method or process to connect with the community (Richardson 2005, Richardson and Winefield 2007, Lee 2009).

Authorities are dealing with increasingly diverse interest groups and communities (Scott et al. 2004, Richardson 2005, Lee 2009), therefore flexibility is a critical component for successful connection (Houston \& Katavic 2006). The Act also requires greater rigour with respect to local authority decision-making processes compared to previous legislation (Richardson 2005, Richardson \& Winefield 2007, Lee 2009) and allows for the process to be adapted to differing circumstances (Richardson 2005, Richardson \& Winefield 2007). As well, it provides principles to ensure councils take account of the impact of decisions on community well-being, affected people and community goals (Richardson 2005, Richardson \& Winefield 2007, Lee 2009). 
The community outcomes process requires authorities to engage the community to identify priorities and long-term goals (Richardson \& Winefield 2007, Lee 2009). The purpose is to increase participation (Lee 2001) and ensure the aspirations of the community are understood and can be used to guide and inform the activities of councils and organizations in the community.

Once agreed, local authorities are required to report on the community's progress in achieving the community outcomes (Controller and Auditor-General 2006a, Quality Planning 2009, Richardson 2005). Monitoring is identified as a key component in effective community involvement and a key aspect of reducing community frustration with process (Wholey \& Hatray 1002, Richardson 2005). This prescription in the Act completes the iterative planning cycle and provides accountability in the process (Richardson 2005). Local authorities are required to provide opportunities for contributions to decision-making by Māori through establishing processes to provide opportunities and fostering capacity among Māori to participate (Richardson 2005, Richardson \& Winefield 2007). Some researchers consider that this provision has addressed the Treaty of Waitangi in regard to decision-making, and potentially a new constitutional convention for Māori, putting iwi on the same footing as a branch of government (Thomas \& Memon 2005). The provisions of the LGA thus provide a balanced toolbox of both prescriptive and flexible measures to enable connection and accountability to the community (Richardson 2002, Richardson \& Winefield 2007). The Act's provisions described above, and its consultation principles (which have been carried through into related legislation such as the Resource Management Act 1991 and the Land Transport Management Act 2003) reflect the evolving body of 'best practice' and academic and practitioner research on effective community engagement and partnership; however, policy does not automatically translate into practice (Houston \& Katavic 2006).

As noted earlier, various reviews (Local Government Rates Inquiry 2007, Richardson \& Winefield 2007, LGC 2008) and audits (Controller and Auditor-General 2005, Controller and Auditor-General 2006a, Controller and Auditor-General 2006b, Controller and Auditor-General 2009) of the LGA 2002 have found that the main weakness does not necessarily lie in the legislation but in the practice of long-term planning (Richardson \& Winefield 2007). This is consistent with the literature, which identifies that 'best 
practice' is difficult to identify given the diverse groups and issues local government is required to deal with (Robinson et al. 2005, Houston \& Katavic 2006, Hughes 2007).

As to be expected with new legislation, there were concerns in initial audits about individual interpretation of the LGA provisions by councils (Controller and AuditorGeneral 2005, Controller and Auditor-General 2006a, Controller and Auditor-General 2006b, Richardson \& Winefield 2007, Controller and Auditor-General 2009). The auditor considered that time and experience would rectify these issues (Controller and Auditor-General 2005, Controller and Auditor-General 2006a, Controller and AuditorGeneral 2006b, Richardson \& Winefield 2007, Controller and Auditor-General 2009). Yet it is evident from several audits that councils are still struggling to interpret core provisions (Controller and Auditor-General 2005, Controller and Auditor-General 2006a, Controller and Auditor-General 2006b, Controller and Auditor-General 2009).

The audits have also shown that the increased flexibility afforded to councils can be a weakness. Whilst some authorities have instituted a variety of engagement and partnership mechanisms, others are doing little more than the bare minimum to legitimize policy (Controller and Auditor-General 2005, Controller and Auditor-General 2006a, Controller and Auditor-General 2006b, Richardson \& Winefield 2007, Controller and Auditor-General 2009). It is also important to recognise that the LGA 2002 promotes, and indeed requires, council-community engagement and partnerships by an already over-burdened society (Dixon et al. 1997, Chess 2000). Despite recognition of consultation fatigue and overload, a heavy reliance on consultation to determine longterm goals may result in only extremist views being represented (Campbell \& Marshall 2000). Likewise, the core assumptions of the LGA 2002 with regard to empowerment rely on a diversity of participants being engaged in local authority decision-making and long-term planning (Robinson et al. 2005). As the literature shows, this is difficult to achieve given intensifying trends towards social exclusion (Campbell \& Marshal 2000, Robinson et al. 2005).

Another weakness identified in the audits concerns the capacity not only of councils to implement and interpret the provisions, but also the capacity of the community to effectively participate (Wallis \& Dollery 2002, Robinson et al. 2005, Memon \& Thomas 2006). Not all councils, community groups, or individuals have access to the necessary skills, time or resources (Wallis \& Dollery 2002, Robinson et al. 2005, Memon \& 
Thomas 2006, Richardson \& Winefield 2007) to be able to effectively contribute or participate, thereby not only according unwarranted significance to the views of only a section of society but legitimizing it as the 'community view' (Robinson et al. 2005).

Despite the weaknesses, the audits consider this can be rectified by appropriate central government leadership and through dissemination of 'best practice' policy (Richardson \& Winefield 2007). However, as the literature has shown, 'best practice’ remains elusive given the varied nature of communities and the challenge of integrating participation, engagement and partnership with the representative role of elected local government (Lane \& Corbett 2005, Robinson et al. 2005, Houston \& Katavic 2006, Nyseth 2010).

\section{Reinventing Local Government... Again?}

Prior to the 2008 general election, the local government policies of the main opposition to the then Labour-led government focused on the need for efficiency, streamlining bureaucracy, and controlling costs (see ACT 2009, AUT University, National Business Review 2008). To form government, the conservative National Party formed a coalition with the libertarian ACT Party, a strong advocate of reductions in the size and scope of councils, and rate-capping. The new Minister of Local Government is the parliamentary leader of the ACT Party.

Following a review initiated by the Minister, and agreed by Cabinet in April 2009, the Local Government Act 2002 Amendment Bill 2010 was introduced to Parliament a year later at the end of April 2010. The select committee report on the Bill is not due until November 2010 so the final form of the Bill is not yet known. The review undertaken during 2009 focused on transparency, accountability and financial management in local government and hence became known as the TAFM Review. Of particular interest for our present purposes are the implications of the review for long-term community planning, which is a particular focus of the Bill. The Minister for Local Government (2010:2) asserted that the intention of the amendments is to 'enable ratepayers to exert greater influence on the work of their councils'. Specifically, these reforms will:

- provide ratepayers and residents with better information about council costs, rates and activities, enabling them to understand and influence planning and decision-making processes;

- introduce pre-election reports, to stimulate debate during council elections;

- simplify long-term planning processes and give them a more strategic focus; 
- achieve plain English financial reporting, so that ratepayers can understand what they are paying for, and how; and

- reduce restrictions on the use of the private sector to deliver council services, improving councils' flexibility to choose effective and efficient delivery methods for water and other services.

Long-term council community plans (LTCCPs) will continue to cover a ten-year timeframe and will still be produced every three years but the Minister's intention is that they become broad strategy documents rather than the detailed and dense documents currently produced. Some changes to the process of long-term community planning appear to be cosmetic. For example, the Bill proposes a new definition of community outcomes, which are to be defined as "outcomes that a local authority aims to achieve in order to maintain and improve the social, economic, environmental, and cultural wellbeing of its district or region”. This change seems to be largely semantic. ${ }^{4}$ Likewise, the Bill proposes a definition of core services to be provided by local government. It has been argued by some critics that because communities by their very nature are many and varied, it is not appropriate to define core services as this does not allow for sufficient acknowledgement of the diversity of councils and communities. However, the definition is broader than some commentators expected (and, arguably, the Minister for Local Government hoped) with both network infrastructure and community infrastructure included. To a degree, then, the status quo is unchanged with this definition. Indeed, the New Zealand Society of Local Government Managers (SOLGM) wrote somewhat wryly in its April 2010 newsletter:

We have received advice that this clause is symbolic at best, and we advise people to avoid inadvertently giving it meaning by playing with it (Horan 2010: 33).

Other provisions are more substantive and potentially far-reaching in terms of their implications for long-term community planning. The intention is to streamline the longterm planning process but the proposed amendments if adopted will potentially diminish accountability, transparency and public participation. The Bill proposes the repeal of sections 91 and 92, which require a local authority to identify and report separately on the progress made towards achieving community outcomes, because the community outcomes process is to be merged with the long-term plan.

\footnotetext{
${ }^{4}$ In referring to the lack of change in semantic terms, we acknowledge that there may be subsequent changes in practice by councils as suggested by one reviewer. Such changes would not be mandated by the Bill if passed as currently drafted. However, we acknowledge that changes to consultation requirements may result in a de-emphasis on the 'four well-beings', particularly social and cultural well-being.
} 
Similarly controversial is the Bill's requirement that local authorities operate within a defined fiscal envelope. This is viewed by critics as imposing a 'sinking lid' on expenditure and limiting councils' ability to respond to changing and diverse community needs. Over time, it is feared, the cap on spending will lead to cutbacks in services. The Bill provides for extended leases on water infrastructure from the current fifteen years to thirty-five years. Given the growing importance of the management and supply of freshwater with increased demand as a result of population growth and lifestyle drivers, and the status of water services as a core service of local government, this is a critical issue for long-term community planning. Finally, the Bill proposes that a pre-election report be issued by a local authority chief executive before each triennial general election to provide information to promote public discussion of the issues facing the local authority. The report must be published no later than two weeks before the date on which nominations close for candidates at the election. It is hoped that this will also engender improvements in voter turnout at local elections.

As noted above, the final form of the amending legislation remains to be determined following the select committee's report due in late 2010 and subsequent revisions and parliamentary debates. However, it is clear that there have already been policy losses for the Minister as a result of discussions within Cabinet about the scope of the reforms. Of note, is that the long-term planning process has not been rejected. To have jettisoned it would have been contrary to a large body of scholarly and practitioner literature, as well as a body of good practice, that affirms the importance of strategic planning in both the public and private sectors.

With the fundamentals of long-term community planning intact, and transparency in some ways enhanced (notably, the pre-election report and simplified LTCCP) but in other ways possibly diminished (reduced consultation over some policies that were previously included in the LTCCP but now removed), what are the associated impacts on public participation - itself a key mechanism for accountability - and for the wider process of local governance of which community-led strategic planning has been a central element?

The Minister considers reforms "represent significant progress towards better local government, and towards easier and more effective participation by ratepayers and 
residents in the activities and decisions of councils" (Minister of Local Government 2010: 2, emphasis added). The Minister's assumption, in promoting change to the longterm planning process, appears to be that the process does not adequately provide for participation by citizens. This is inconsistent with findings of the Local Government Commission (2008) as part of its review of the Local Government Act 2002 and Local Electoral Act 2001, that there is positive engagement by citizens with councils in longterm planning and that councils value the requirement to undertake long-term planning. The Local Government Commission argues that reliance on the use of the traditional approach of submissions in response to a public notice (the 'special consultative procedure' as it is termed in the Local Government Act) is problematic and recommends that councils use more effective consultation mechanisms. The limited provisions for participation at council meetings, reliance on traditional public meetings and communication via public notices, along with deficiencies in the electoral system have exacerbated the long downward trend in voter turnout since the 1980s. This concurs with two paradoxes associated with governance approaches:

Firstly, despite accounts of the 'hollowing out' of the state as a result of an increasing plurality of governance arrangements, the power of the state is not necessarily diminished. Secondly, even when governments genuinely appear to do all they can to facilitate citizen participation, these efforts do not necessarily empower citizens. At the heart of both paradoxes lies the persistence of traditional forms of government (Blakely, 2010: 131).

\section{Conclusion}

The LGA 2002 provides a mandate for New Zealand local authorities to undertake community planning with explicit provisions for engaging and being accountable to the communities they serve. This Act was born out of growing dissatisfaction with cumbersome, reactive and prescriptive legislation with a limited strategic outlook, and growing public consciousness of sustainability. It resulted in a rebalancing of the relationship between communities and local government (Scott et al. 2004, Houston \& Katavic 2006), following trends internationally towards a network approach to governing. Collaboration and partnership were hailed as the new core principles for local government to develop and achieve a prosperous shared future (Houston \& Katavic 2006). The literature on engagement clearly indicates benefits are to be had, but considers 'best practice' is difficult given the diversity of communities and their capacity to participate in meaningful engagement (Lane \& Corbett 2005, Houston \& Katavic 2006, Smith et al. 2006, Taylor 2006, Hughes 2007). Similarly, research on partnerships attests to its effectiveness, but finds that issues around power-sharing and process can 
undermine its effectiveness (Slack 2004, Robinson et al. 2005, Smith et al. 2006, Taylor 2006, Hughes 2007).

The LGA 2002 provides a mixture of prescription and flexibility in terms of engaging and collaborating with the community for long-term planning (Scott et al. 2004, Richardson \& Winefield 2007). The Act's main strength lies in the options it provides for connecting with the community (Richardson \& Winefield 2007), but its weakness lies in its interpretation and implementation by some local authorities (Controller and Auditor-General 2006a, Controller and Auditor-General 2006b, Richardson \& Winefield2007, Controller and Auditor-General 2009). Reviews and audits have recommended further policy measures to improve performance but, given the diversity of the community and the range of the issues that need to be addressed, it may be impossible to achieve uniformly satisfactory results.

In summary, there has been a noticeable trend both in New Zealand for devolution from central government to local government and for broader citizen participation in government planning and decision-making processes at all levels (Mulgan 1994, Wood \& Rudd 1996). Although the stated purpose of the various government reforms have been efficiency (Mulgan 1994, Wood \& Rudd 1996), economics and market stability (Mulgan 1994), it is clear that there has been a significant paradigm shift with respect to participatory governance networks. Although introduced by 'decree' by central government, in the form of statutory requirements, community-led strategic planning is a response to aspirations from communities and also from the local government sector to undertake strategic planning involving the range of local stakeholders whose efforts need to be harnessed in order for the desired outcomes to be achieved. Whilst there have been challenges to overcome (not least the development of capacity among elected members, local authority staff and citizens), and progress still to be made (in particular, in achieving alignment of central and local government strategies and in engaging many hard-to-reach sectors), the passage of the Local Government Act 2002 undoubtedly resulted in a quantum leap forward in community-led strategic planning in New Zealand as evidenced by, among other things, survey data on New Zealanders' familiarity with the LTCCP (LGC, 2008). Whether these achievements will be sustained, and further gains made, is not certain. 
Despite several government reviews and audits indicating no major flaws with the current framework, the new central government has embarked on a road of major reform that has the potential to undermine the basic assumptions of community planning. If planning and decision-making become disengaged from the community, a future may be created that no one wants, by an authority that no one engages with or trusts.

Although the tide may be turning for community-led strategic planning in New Zealand with proposed changes to the LGA 2002, it is far from turning internationally. ${ }^{5}$ Despite the paradoxes referred to above, and also the danger in over-optimism about the new institutional forms of participation, Blakely (2010: 141) notes that: "Participation has its own dynamism and displays a constant tendency to escape the channels and structures which work to institutionalize it.” The 'empowerment genie' having been released is unlikely to be contained and the broader historical trend towards participatory governance networks and devolution is likely to prevail.

\section{References}

ACT Party (2009). Kiwis could learn from British welfare reform plan. Retrieved on 1 June 2009 $<$ http://www.act.org.nz/media?keys=bureaucracy\&taxonomy-operator=1\&taxonomyterms $\% 5 B \% 5 \mathrm{D}=155>$.

Atkinson, N. (2003). Adventures in democracy: A history of the Vote in New Zealand. New Zealand: University of Otago Press.

AUT University (2008). Local government newsletter. Retrieved on 1 June 2009 $<$ http://www.ipp.org.nz/lgnewslettermarch 09.html $>$.

Beatson, D. (2009). Super-City: the shape of things to come. Retrieved on 1 June 2009 <http://pundit.co.nz/content/Super-city-\%62\%80\%93-the-shape-of-things-to-come>.

Berger, G. (2003). Reflections on governance. Power relations and policy making in regional sustainable development, Planning Theory and Practice 5(3): 219-234.

Blakely, G. (2010). Governing Ourselves: Citizen Participation and Governance in Barcelona and Manchester. International Journal of Urban and Regional Research 34:130-145.

Bush, G. (1990). The Historic Reorganization of Local Government. In M. Holland and J. Bostin (Ed.)in The fourth labour government: Politics and policy in New Zealand ( $2^{\text {nd }}$ Ed), New Zealand: Oxford University Press.

Bush, G.W.A. (1980). Local Government and Politics in New Zealand. Australia: George Allen \& Unwin.

Business New Zealand (2001). Submission by Business New Zealand to the Department of Internal Affairs on the Consultation Document Reviewing the Local Government Act 1974. Retrieved on 1 June 2009 <http://www.businessnz.org.nz/file/297/010830LocalGovtActReview.pdf>.

\footnotetext{
${ }^{5}$ In the United Kingdom, for example, the new Conservative government has introduced a Decentralisation and Localism Bill which includes a power of general competence. See http://www.number10.gov.uk/queensspeech/2010/05/queens-speech-decentralisation-and-localism-bill-50673
} 
Campbell, H., Marshall, R. (2000). Public involvement and planning: looking beyond the one to the many. International Planning Studies. 5(3):321-344.

Chess, C. (2000). Evaluating environmental public participation: methodological questions. Journal of Enviornmental Planning and Management. 43(6):769-784.

Cheyne, C. (2002). Central government and its role in community planning. In M. ThomsonFawcett \& C. Freeman (Eds.) Living together: towards inclusive communities. Dunedin: Otago University Press.

Cheyne, C. (2006). Public involvement in local government in New Zealand: a historical account. In J. Drage (Ed.) Empowering communities? representation and participation in New Zealand's local government. Wellington: Victoria University Press.

Chhotray, V., Stoker, G. (2010), Governance Theory and Practice. A Cross Disciplinary Approach. Houndmills, Palgrave Macmillan.

Controller and Auditor-General (2005). Local government: results of the 2005/06 audits. Retrieved on 1 April 2009 <http://www.oag.govt.nz>.

Controller and Auditor-General (2006a). Matters Arising from the 2006-2016 Long-term Council Community Plans. Parliamentary Paper. Retrieved on 1 April 2009 $<$ http://www.oag.govt.nz $>$.

Controller and Auditor-General (2006b). Local Government: Results of the 2006/07 Audits. Retrieved on 1 April 2009 <http://www.oag.govt.nz>.

Controller and Auditor-General (2009). Reporting on effects of activites in the annual report. Retrieved on 1 April 2009 <http://www.oag.govt.nz/local-govt/2004-05/part1-3.htm>.

Controller and Auditor-General (2010). Local government: examples of better practice in setting local authorities’ performance measures, Retrieved on 17 June 2010 http://www.oag.govt.nz/2010/examples-of-better-practice.

Cousins, M. (2002). Capturing the citizens voice: The use of referenda by New Zealand Local Government. In J. Drage (Ed.) Empowering communities?: Representation and participation in New Zealand's local government. Wellington: Victoria University Press.

Cowell, R. (2004). Community planning: fostering particiaption in the congested state? Local Government Studies. 30(4):497-518.

Dann, C. (1992). Government: Representation and Trust. In D. Novitz and B. Willmott (Ed.) New Zealand in Crisis: A debate about today's critical issues. Wellington: GP Publications Limited.

Department of Internal Affairs (2000). Statement of policy direction for review of Local Government Act 1974. Retrieved on 1 June 2009 <http://www.dia.govt.nz/PUbforms.nsf/URL/Discussion.pdf/\$file/Discussion.pdf>.

Department of Internal Affairs (2001). Reviewing the Local Government Act 1974: Consultation Document. Wellington: Department of Internal Affairs.

Department of Internal Affairs (2009). Local government legislation. Retrieved on 19 September 2009 <http://www.localcouncils.govt.nz/lgip.nsf/wpg url/About-Local-GovernmentLocal-Government-Legislation-Index $>$.

Dixon, J.E., Ericksen, N.J., Crawford, J.L., Berke, P. (1997). Planning under a co-operative mandate: new plans for New Zealand. Journal of Environmental Planning and Management. 40(5):603-614.

Eames, D. (2009). Hide to review 'farcical' planning law. Retrieved on 1 June 2009 <http://www.beehive.govt.nz/release/community+well-being+strong+motivator>.

Freeman, C. (2004). Sustainable development from rhetoric to practice? A New Zealand perspective. International Planning Studies. 9(4):307-326. 
Geddes, M. (2005). Neoliberalisim and local governance - Cross-national perspectives and speculations. Policy Studies, 26:359-377.

Geddes, M. (2006). Partnership and the Limits to Local Governance in England: Institutionalist Analysis and Neoliberalism. International Journal of Urban and Regional Research 30:76-97.

Guaranos-Meza, V. \& Geddes, M. (2010). Local Governance and Participation under Neoliberalism: Comparative Perspectives. International Journal of Urban and Regional Research, 34:115-129.

Gwynn, R. (1998). The denial of democracy. New Zealand: Cosmos Publications.

Hansard (2009). Urgent Debates: Royal Commission of Inquiry into Auckland Governance Government Response. Retrieved on 1 June 2009 <http://theyworkforyou.co.nz/urgent_debates/2009/apr/08/royal_commission_of_inquir y_into_2>.

Head, B.W. (2007). Community engagement: participation on whose terms? Australian Journal of Political Science. 42(3):441-454.

Haus, M., Heinelt, H., Stewart, M. \& (eds.) (2004). Urban governance and democracy : leadership and community involvement. New York: Routledge.

Hewison, G.J. (2008). The Local Government Act 2002: rationalization or reform? Retrieved on 1 June 2009 <http://researchspace.auckland.ac.nz/2292/2877>.

Horan, R. (2010). TAFN - What's next? Pulse, April, 33-34.

Houston, D., Katavic, M. (2006). Quality in a New Zealand Local Authority: A case study. Total Quality Management and Business Excellence. 17(4):425-438.

Hughes, J. (2007). Lost in translation: communities of practice - the journey from academic model to practioner tool. In J. Hughes, N. Jewson, \& L. Unwin (Eds). Communities of practice: critical perspectives. New York: Routledge.

Humpage, L. (2009). Submission to the Royal Commission on Auckland Governance. Retrieved on 1 June 2009 <www.royalcommission.govt.nz>.

Kelsey, J. (1993). Rolling back the state: privatisation of power in Aotearoa/New Zealand. Wellington: Bridget Williams Books.

Klijn, E-H. (2008) Governance and Governance Networks in Europe. An assessment of ten years of research on the theme, Public Management Review 10(4): 505-525.

Lane, M.B., Corbett, T. (2005). The tyranny of localism: indigenous participation in communitybased environmental management. Journal of Environmental Policy \& Planning. 7(2):141-159.

Larner, W., Craig, D. (2005). After neoliberalism? Community activism and local partnerships in Aotearoa New Zealand. Antipode. 37(3):402-424.

Lee, S. (2009). Keynote speech to Local Government Human Resources conference. Retrieved on 1 April, 2009, <http://beehive.govt.nz/speech/keynote+speech+local+government+human+resources+ conference $>$.

Leonard, L., Memon, A. (2008). Community outcome processes as a forum for community governance. Retrieved on 1 June 2009 <http://www.waikato.ac.nz/igci/pucm/lga/lgarpt3.pdf>.

Local Futures (2006). Local Government, Strategy and Communities, Institute of Policy Studies, Victoria University of Wellington.

Local Government Commission (2008). Review of the Local Government Act 2002 and Local Electoral Act 2001. New Zealand: Local Government Commission. 
Local Government New Zealand (2003). The Local Government Act 2002: an overview. Retrieved on 25 October 2009

<http://www.lgnz.co.nz/library/publications/KnowHow_Guide____LGA_2002.pdf>.

Local Government New Zealand (2009). The Local Government Act 2002 and its implications. Retrieved on 19 September 2009 <http://www.lgnz.co.nz/library/6255_section_2-ffweb.pdf>.

Local Government Rates Inquiry (2007). Funding local government. Retrieved on 1 June 2009 $<$ http://www.ratesenquiry.govt.nz $>$.

Martin, S. (2003). Engaging with citizens and other stakeholders. In A.J. Govaird \& E. Loffler (Eds). Public Management and Governance. London: Routledge.

McRobie, A. (1985). The electoral system: representing people or electing a dictatorship? In H. Gold (Ed.) New Zealand Politics in Perspective. Auckland: Longman Paul.

Memon, A. (2002). Reinstating the purpose of planning within New Zealand's Resource Management Act. Urban Policy and Research. 20(3):299-308.

Memon, A., Thomas, G. (2006). New Zealand's New Local Government Act: a paradigm for participatory planning or business as usual? Urban Policy and Research. 24(1):135144.

Miller, C. (2006). New directions in New Zealand's urban planning and research. Urban Policy and Research. 24(3):341-354.

Minister of Local Government (2009). Making Auckland Greater: The Government’s decisions on Auckland Governance. Retrieved on 1 June 2009 <http://www.auckland.govt.nz/web/cms_rcauckland.nsf/vwluResources/making_ak_gr eater_report_vl/vl/\$file/Making\%20Ak\%20Greater\%20final\%20WEB_v2.pdf>.

Minister of Local Government, 2010, Decisions for better transparency, accountability and financial management of local government: Local Government Act 2002 Amendment Bill, Wellington: Office of the Minister of Local Government.

Ministry for the Environment (2009a). Implementing your LTCCP. Retrieved on 1 October 2009 <http://www.mfe.govt.nz/withyou/envwell-being/implementing.html>.

Ministry for the Environment (2009b). Promoting environmental well-being under the Local Government Act 2002. Retrieved on 1 April, 2009 <http://www.mfe.govt.nz/withyou/envwell-being/index.html $>$.

Mulgan, R. (1994). Politics in New Zealand. New Zealand: Auckland University Press.

Myers, D. (1998). Local Government: Time for a New Blueprint. Retrieved on 1 June 2009 <http://www.nzbr.org.nz/documents/speeches/speeches-98/local-government-time-fora-blueprint.doc.html>.

National Business Review (2008). Full wrap of parties’ election policies. Retrieved 1 June 2009 <http://www.nbr.co.nz/article/full-wrap-parties-election-policies-37400>.

New Zealand Government (2009). Local Government Act 2002. Retrieved on 1 April 2009 <http://www.localcentral.govt.nz/web.outcomes.nsf/unid/CFIN7FG3FM?OpenDocument>.

New Zealand Institute of Economic Research (2009). Auckland's governance reforms: how far will the ripples spread? Retrieved on 1 June 2009 <http://www.ipp.org.nz/localgovtfiles/conference/Wellington\%20Workshop\%20Papers /An\%20\%economic\%perspective\%20on\%20four\%20well-beings.pdf>.

Nyseth, T., Ringholm, T. (2008). Municipal response to local diversity: flexibility in community governance. Local Government Studies. 34(4):471-487.

Nyseth, T. (2010). Network governance in contested urban landscapes, Planning Theory and Practice 9(4): 497-514. 
Perkins, H.C., Thorns, D.C. (2001). A decade on: reflections on the Resource Management Act 1991 and the Practice of urban planning in New Zealand. Environment and Planning B: Planning and Design. 28:639-654.

Pierre, J. ed. (2000). Debating Governance: Authority, Steering, and Governance. New York: Oxford University Press.

Quality Planning (2009). Relationship between the Local Government Act and the RMA. Retrieved on 1 April 2009 <http://www.qp.org.nz/related-laws/fag-rma-lga.php>.

Reddel, T. (2002). Beyond participation, hierachies, management and markets: new governance and place policies. Australian Journal of Public Administration. 61(1):50-63.

Rhodes, R.A.W., (1996), The New Governance: Governing without Government, Political Studies, XLIV:. 652--667.

Rhodes, R.A.W. (1997) Understanding governance: policy networks, governance, reflexivity and accountability. Buckingham: Open University Press.

Richards, A. (2002). The Local Government Act Review - highlights of the local government Local Government Bill 2009. New Zealand Petroleum Conference Proceedings. February:24-27.

Richardson, M. (2005). Reflections on what was achieved in the Local Government Act 2002. Retrieved on 1 June 2009

<http://www.waikato.ac.nz/igci/pucm/Linked\%20documents/Mike\%20Richardson\%20 Response.pdf $>$.

Richardson, M., Winefield, P. (2007). Review of the Local Government Act 2002: Engagement and decision-making provisions. Retrieved on 1 June 2009 $<$ http://www.lgc.govt.nz/lgcwebsite.nsf/Files/ReviewLGacEngageDecisionProvisons/\$ file/ReviewLGactEngageDecisionProvisions.pdf $>$.

Rive, V. (2003). Local Government Act 2002: free at last? NZ Environment. 26:14-27.

Robinson, F., Shaw, K., Davidson, G. (2005). On the side of angels: community involvement in the governance of neighbourhood renewal. Local Economy. 20(1):13-16.

Royal Commission on Auckland Governance (2009). Royal Commission on Auckland Governance: Report. Retrieved on 1 June 2009

<http://www.royalcommission.govt.nz/rccms.nsf/0/B764F57542CB4EC1CC25758500 570729?open>.

Scott, C., Reid, M., Yeabsley, J., Zollner, E. (2004). Local government’s role in strategic policy and planning. Retrieved on 1 June 2009

<http://myfrst.frst.govt.nz/Public/ResearchReports/CD05/html/reports/vicx0305.html>.

Slack, K. (2004). Collaboration with the communty to widen participation: partners whitout power or absent friends. Higher Education Quarterly. 58(2/3):136-150.

Smith, M., Mathur, N., Skelcher, C. (2006). Corporate governance in a collaborative enviornment: what happens when government, busienss and civil society work together. Corporate Governance. 14(3):159-171.

Society of Local Government Managers (2009a). Piecing it together. Retrieved on 1 October 2009 $<$ http://www.solgm.co.nz/Other+SOLGM+Good+Practice+Material/Piecing+It+All+T ogether.htm>.

Society of Local Government Managers (2009b). Funding and financial policies. Retrieved on 19 September $2009<$ http://www.solgm.co.nz/NR/rdonlyres/82FDECAA-A4D8-439F9167-F800717F01A2/49558/PIT2Funding.pdf $>$.

Sterling, R. 2005. Promoting democratic governance through partnerships? In: Newman, J. (ed.) Remaking governance. People, politics and the public sphere. Bristol: The Policy Press. 
Stoker, G. 1998. Governance as theory: five propositions. International Social Science Journal.50:17-28.

Tenbensel, T. 2005. Multiple modes of governance: Disentangling the alternatives to hierarchies and markets. Public Management Review. 7:267-288.

Taylor, M. (2006). Communities in partnership: developing a strategic voice. Social Policy \& Society. 5(2):269-279.

Thomas, S., Memon, A. (2005). Reinventing local government in New Zealand? A critical reflection of the Local Government Act 2002. Retrieved 1 June 2009 <http://www.waikato.ac.nz/igci/pucm/Linkend\%20documents/LGA-discussion.pdf>.

Uitermark, J., Duyvendak, J.W. (2008). Citizen participation in a mediated age: neighbourhood governance in the Netherlands. International Journal of Urban and Regional Research. 32(1):114-134.

Wallis, J., Dollery, B. (2002). Local government capacity and social capital. Retrieved on 1 April 2009 < http://eprints.otago.ac.nz/245/1/DP0207.pdf>.

Wholey, J.S., Hatray, H.P. (1992). The case for performance monitoring. Public Administration Review. 52(6):604-610.

Wilson, V., Salter, J. (2003). A guide to the Local Government Act 2002. North Shore City. Thomson/DSL Publishing.

Waiheke Island Sustainable Development Group (2007). Sustainability as a community and governance issue: Waiheke Island and the Hauraki Gulf- a case study. Retrieved on 1 April 2009

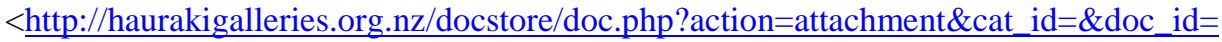
$\underline{203}>$.

Wood, G.A. (1988). Governing New Zealand. Auckland: Longman Paul.

Wood, G.A., Rudd, C. (1996). The politics and government of New Zealand: robust, innovative and challenged. Dunedin: University of Otago Press. 